\title{
NEW NEUROPTERA AND TRICHOPTERA FROM THE UNITED STATES ${ }^{1}$
}

\author{
By Nathan Banks
}

In the course of identification of Neuropteroid insects in the Museum of Comparative Zoölogy several species were found that are new. Descriptions of these are given, and further studies with additional material enable one to prepare a synopsis of our small species of Myrmeleon.

\section{ORDER NEUROPTERA}

\section{Chrysopid $\approx$ e}

Chrysopa sperryx sp. nov.

Pale greenish; head, antennæ, and legs more yellowish; pronotum with a median yellowish stripe, extending back on mesonotum; both pairs of palpi marked with black, otherwise without dark marks, no dark nor reddish on cheeks. Wings with green venation, the only black is on the first (and sometimes second) branch from cubitus to the cubital fork. Stigma long, plainly green.

The fore wings have eleven radial cross-veins, six cubitals beyond the divisory cell, latter ending before cross-vein above; about six inner gradates and seven outer, the rows nearly parallel, each gradate separated from the next by more than its length, except the two or three at upper end of outer row; hairs on veins about as in $C$. plorabunda. The costal area (at broadest) almost as broad as the radial area, and each about equal to the post-cubital area, latter fully one-third broader than cubital area; subcostal area of stigma with but one or two crossveins.

In hind wings eight or nine radials; three inner gradates, and four or five outer ones, in nearly parallel series, and well separated.

\footnotetext{
${ }^{1}$ Published with the aid of a grant from the Museum of Comparative Zoölogy at Harvard College.
} 
Length of fore wing 10 to $12 \mathrm{~mm}$.

From Riverside, Calif. 22 August to 19 September, from Grace H. and John L. Sperry; also two from Lake Arrowhead, Calif., 29 August (Buckwalter coll.). Type M.C.Z., No. 25753.

Readily separated from all others in the plorabunda section by the absence of dark or reddish marks below the eyes.

\section{MyrmeLEONIDÆ}

Vella texana minor var. nov.

Acanthaclisis fallax Rambur was described from "Guyane"; Hagen identified specimens from Mexico as this, and in my Revision of the Myrmeleonidæ (1927) I kept the Mexican and Arizonian specimens under that name. Now I have seen specimens from Guiana, and ours is a different form.

It is in many particulars like $V$. texana Hagen, so I describe it as a variety of that species.

It is uniformly a little smaller, fore wing from 48 to $51 \mathrm{~mm}$. long (texana 54 to $56 \mathrm{~mm}$.) but the wing scarcely more narrow; the tip is very plainly less pointed, the hind margin before tip not or scarcely concave (in texana plainly so). As noted in my Revision, the venation is more dense, but not as heavily marked. The costal area has a number of cells before middle that are crossed, while in texana there are few or none. The markings on body are similar; on pronotum the pale areas are paler than in texana, and the dark on mesoscutellum is divided by a fine pale line.

The male appendages of minor are plainly a little shorter than in texana.

The type is from Phoenix, Arizona, paratypes from Tucson, 6 to 9 August and 6 September. M.C.Z., No. 25758.

Myrmeleon carolinus sp. nov.

In general much like $M$. crudelis Walker from Florida. It is readily separated by the last joint of labial palpi being much less swollen, and in the male the abdomen is plainly a little longer and more slender. In the female of crudelis there is a large triangular pale spot on each side of the last segment of the abdomen, in carolinus none or a faint line. The hair on abdomen is fully as long as in crudelis. The wings of carolinus 
are not as broad, and the dark marks on veins are not as distinct as in crudelis.

The specimens average a little smaller in size than crudelis.

Many specimens taken at Southern Pines, North Carolina, by Mr. Manee from the latter part of May until August, also
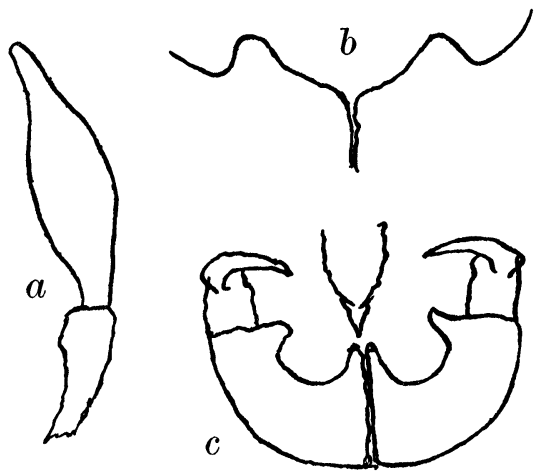

Fig. 1. (a) Labial palpus of Myrmeleon carolinus, n.sp.; (b) Base of $\hat{\delta}$ claspers from behind of Banksiola "concatenata" Walker; (c) $\hat{\partial}$ claspers from behind of Banksiola crotchi, n.sp.

several from Millin, Scriven Co., Georgia, July (Morrison). Type M.C.Z., No. 25752.

\section{Myrmeleon arizonicus sp. nov.}

Head black, except lower clypeus and orbits, antennæ black except part of basal joint, last joint of labial palpi much swollen, black. Pronotum black; in front of groove is a median pale line and each side is a rounded pale spot, and outer margin pale; behind the groove is an elongate pale spot each side, behind the spot in the front part; hair white. Thorax black, hind margin of mesonotum narrowly pale; abdomen black, last five segments narrowly pale at tip above, hair short and white, except that last segment of female has short erect black hair as usual. Legs pale; mid and hind femora largely black, and front femora black below; all tibiæ black within, the front also dark on sides; tarsi, except basal joint black.

Fore wings with longitudinal veins plainly streaked with black; cross-veins pale with dark dots, but in apical fourth of wing they are mostly black; hair short and black; hind wings 
with similar venation. Wing slender, acute at tips; fore wings with seven cross-veins before radial sector, nine to eleven radials before stigma, five or six branches of anal; one series of gradates in apical costal area. In hind wings four cross-veins before radial sector, about eight radials before stigma, and five branches to anal; no gradates in apical costal area.

Length of fore wing 21 to $25 \mathrm{~mm}$., width 4.9 to $5.5 \mathrm{~mm}$. Length of hind wing 19 to $23 \mathrm{~mm}$., width 4 to $4.2 \mathrm{~mm}$.

From Tucson, Arizona, 6, 20 June; 6 August; Nogales, Arizona 25 July; El Paso, Texas, 4 July, and Brownsville, Texas, April. Type M.C.Z., No. 25849.

In general similar to $M$. rusticus, but smaller on average, with plainly more slender wings, and cross-veins dotted, vertex usually wholly black, and the last joint of labial palpi rather more swollen.

\section{Myrmeleon californicus sp. nov.}

Face mostly reddish brown, lower part of clypeus and the orbits yellowish, front and vertex deep black, also the antennæ except part of basal joint. Pronotum pale, markings very faint, behind groove is a large broad dark area, and in front a smaller median spot, hair white; thorax black, pruinose; abdomen black, with short white hair, none of segments pale at tips except the last; legs pale, mid and hind femora somewhat embrowned, mid and hind tibiæ with black line within, all tarsi mostly black except basal joint, spines black, spurs almost equal first joint.

Wings hyaline, veins mostly pale, subcosta, radius, and cubitus marked with dark streaks as usual, stigma white; most of venation beyond stigma dark, and some cross-veins behind are dark; hair on veins in costal area mostly black, elsewhere it is largely snow-white, or only the tips of hairs black. Last joint of labial palpi black, except tip, about as much swollen as in M. rusticus.

Wings broad, especially toward tip; in fore wing the apical costal area is expanded in front and just behind the tip of wing is a distinct concavity, so the tip appears slightly falcate. In fore wing seven cross-veins before radial sector, about ten radials before stigma, one series of gradates in apical costal area, six or seven branches of anal vein; posterior part of cubital area almost twice as broad as anterior part; the cubitus 
beyond the forking curves forward more than in most species; in hind wings four cross-veins before radial sector, seven radials before stigma, no gradates in apical costal area, three branches of anal vein.

Length of fore wing $23 \mathrm{~mm}$.; width $5.8 \mathrm{~mm}$. Length of hind wing $21 \mathrm{~mm}$., width $4.8 \mathrm{~mm}$.

One female from Gavilan, California, 11 July (G. H. \&. J. L. Sperry). Type M.C.Z., No. 25850.

\section{Synopsis of the Small Myrmeleons of United States}

1. Two series of cross-veins in apical field of fore wings; vertex usually entirely dark; veins with dark dots (or none), no dark streaks on cross-veins

2.

But one series of cross-veins in apical field of fore wings; vertex often spotted with pale; cross-veins often partly or wholly dark

2. Pronotum with a median dark streak, narrowed in front; veins scarcely dotted with dark; legs not marked with black; at most reddish brown

texanus.

Pronotum with a broad dark mark, containing more or less plainly about five pale spots; veins plainly dotted with dark

3. Last joint of labial palpi much swollen

Last joint of labial palpi slender crudelis. carolinus.

4. Hair on veins, especially toward tip of wing, largely white; apical costal area expanded in front; cross-veins little marked with dark; vertex wholly dark . californicus. Hair on veins black; apical costal area not expanded in front

5. Radials and many cross-veins dotted with dark, not dark in streaks nor wholly so ................. 6 .

Radials and most other cross-veins not dotted, but of an even color, usually dark, or dark in streaks

6. In the hind wings the radius and cubitus at least on basal part are plainly darker than other veins; radial sector also partly dark; mid and hind femora broadly banded with black; scutellum dark; vertex mostly dark; fore wings not 25 millimeters long ........ arizonicus

In hind wings the radius and cubitus not darker than other veins; mid and hind femora largely yellowish brown; scutellum pale; fore wings fully 25 millimeters long 
7. In hind wings radius and cubitus darker than other veins; dark spots on clypeus; fore wings over 25 millimeters long distans.

In hand wings radius and cubitus pale as other veins, most of cross-veins wholly pale; no spots on clypeus; pronotum largely pale; fore wings not over 25 millimeters long ...

diversus.

\section{AsCALAPHID $A$ E}

Ululodes nigripes $\mathrm{sp}$. nov.

Of the general appearance of $U$. senex Burm. The hair on face much darker, that near base of antennæ dark gray; on pleura just below base of fore wings there is also gray hair (instead of the white); the hair on pronotum almost black, that on mesonotum dark gray; most of the hair on pleura is white, but more gray hair than in senex; hair at base of abdomen nearly black. Antennæ nearly evenly black, sometimes a faint dot or narrow line at base of some joints, but not like the broad pale bands of arizonensis and albifrons, the knob of antenna short and black.

Mid and hind tibiæ and tarsi black (sometimes also front pair), densely clothed with black hair and bristles; femora with mostly long white hair as in other species. In the female the antennæ do not reach to the stigma, about five costal cells before it.

Wings hyaline; in female sometimes a dark stigmal band in hind pair; venation black; stigma black, covering four or five cross-veins. The fore wings are a little broader at middle, and a little more acute at tip than in senex.

Fore wing 25 to $26 \mathrm{~mm}$. long.

From Davis Mts., Texas (D. J. \& J. N. Knull) in June, July, and August. Type in Ohio State Univ. Collection; paratypes there and at the M.C.Z., No. 25744.

\section{MANTISPID $\approx$ E}

\section{Manispa uhleri sp. nov.}

Face pale, with a narrow median dark stripe, enlarged on clypeus and on labrum, and also at antennæ where it extends up on front in two dark stripes leaving a pale stripe between them, and extending laterally on vertex to eyes, and also just above antennæ extending laterally to eyes; palpi marked with 
dark; antennæ brown, basal joint pale yellowish; pronotum pale, with a median black line distinct in front and behind, the side margins of anterior lobe also brown; mesonotum with a broad brown area through the middle, and a brown stripe each side above wing-base, a yellowish stripe each side between the brown; abdomen dark brown to black, the tips of some segments narrowly pale; legs yellowish, front femora and tibiæ dark brown, inner side of femora partly pale, the long spine yellowish, others brown.

Wings hyaline, stigma brown, a pale yellowish-brown streak between the subcosta and radius; venation mostly dark brown to black, toward base of wings some veins are pale.

Structure similar to sayi and cincticornis; each radial cell with two or three branches.

Length $14 \mathrm{~mm}$.

Holotype from Pennsylvania, 1858 (P. R. Uhler).

Type M.C.Z. 22132. Paratype, Starved Rock, Ill. 4 Aug. (F. G. Werner).

Differs from sayi and cincticornis in the almost entirely black abdomen, and in that the dark face mark extends upward on front to the vertex.

Specimens from the Field Museum taken at Palos Park, Edgebrook, Lombard, and Dowers Creek in Illinois in July, August, September, and November are paratypes, also from Delaware, Wisconsin. In the females several joints of the antennæ near the apical third are yellowish.

\section{ORDER TRICHOPTERA}

\section{Phryganeid $A$ e}

Banksiola crotchi sp. nov.

In general appearance very similar to the common Eastern species which has been considered (but wrongly) "concatenata"; the fore wings banded and spotted in the same manner, also the apical part of hind wing is marked as in that species; the venation is also on the same plan.

But the claspers of the male show a striking difference; seen from behind each shows two widely separated processes or teeth, one very slender at the extreme inner end, the other much further out is broader and larger. (In "concatenata" so- 
called there is a broad somewhat triangular lobe or plate near the extreme inner end.) The lateral curved median process is about as in the Eastern species, and the penis is about the same. The superior plate (tenth segment) has the apical indentation much as in the Eastern form, but the lateral lobe or process near its base is much larger.

Length of fore wing $12 \mathrm{~mm}$.

Two males from Victoria, Vancouver Island, July (G. R. Crotch). Type M.C.Z. 25956. 

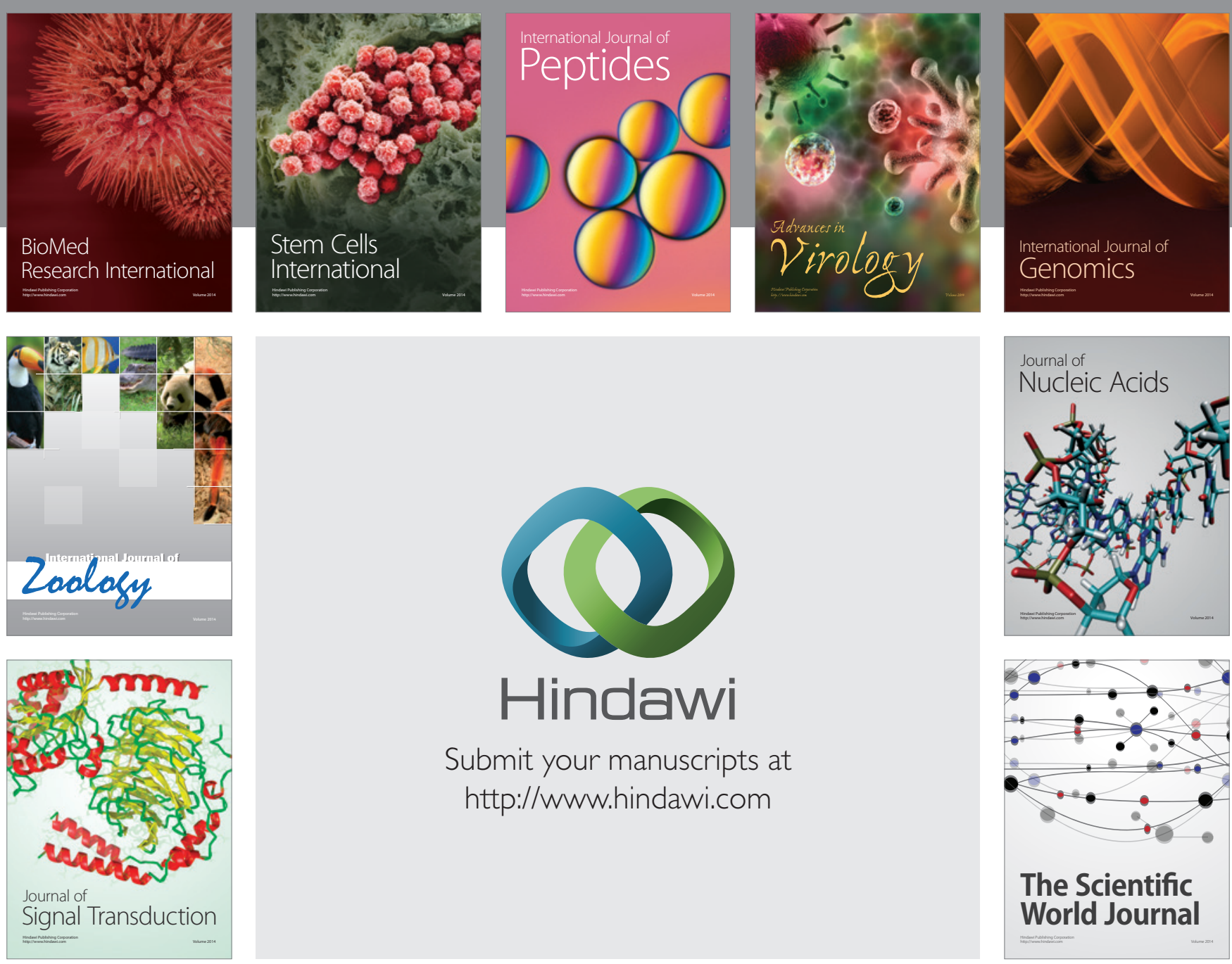

Submit your manuscripts at

http://www.hindawi.com
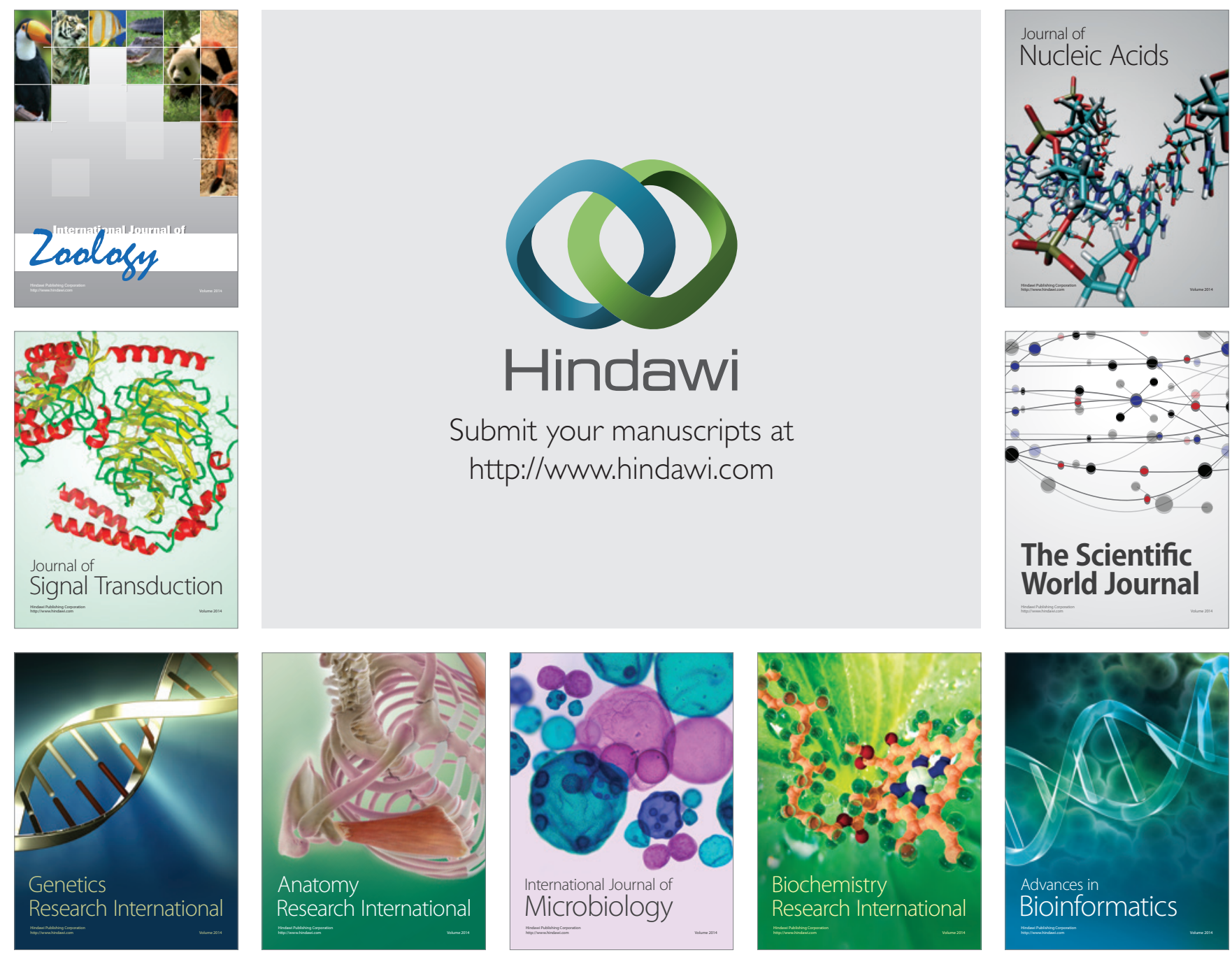

The Scientific World Journal
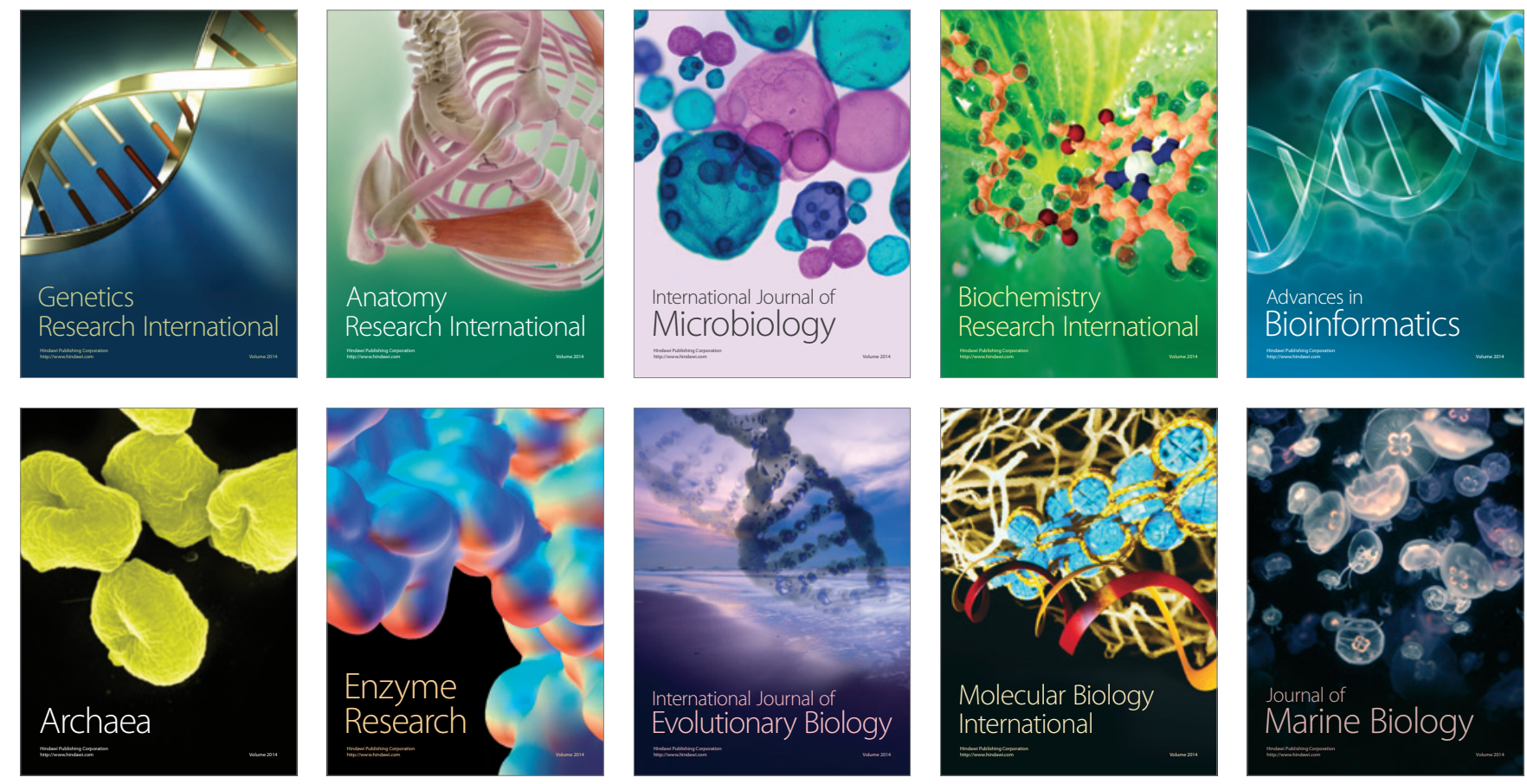